\title{
Integrasi Antara Komisi Pengawas Persaingan Usaha Dan Penyidik Kepolisian Dalam Penegakan Hukum Persaingan Usaha
}

\author{
Sukarmi \\ Fakultas Hukum Universitas Brawijaya Malang Jawa Timur Indonesia \\ Jln. Mt. Harjono 169 Malang Jawa Timur Indonesia \\ sukarmi@ub.ac.id
}

Received: 16 Oktober 2020; Accepted: 7 April 2021; Published: 2 Juni 2021

DOI: 10.20885/iustum.vol28.iss2.art6

\begin{abstract}
The handling of unfair business competition cases by the Business Competition Supervisory Commission (KPPU) cannot run alone without the help and support of other law enforcement agencies, one of which is the Police Investigator. Its support is related to the summoning of the reported, witnesses and expert witnesses, collection of evidence and examinations that contain elements of competition law crimes as mandated by Law Number 5 of 1999. The issues examined in this research are, first, what is the role played by police investigators. in the enforcement of business competition law, has it been integrated with KPPU? second, how is the integration between KPPU and police investigators in enforcing business competition law? This is a normative legal research with a statutory approach and a case approach. The results of the study conclude that the role of Police Investigators in enforcing business competition law begins during the investigation and examination process. KPPU requests assistance to present the reported, witnesses, expert witnesses as well as anyone involved in business competition cases. Then after a decision is issued by the KPPU that has not been filed for objection, the investigator can follow up if it contains a criminal aspect. The integration between the KPPU and the Police Investigators of the Republic of Indonesia is manifested in the form of a Memorandum of Understanding which is then followed up with a cooperation to form a Working Group between KPPU and Police Investigators in handling business competition cases.
\end{abstract}

Key Words: Business competition; integration of KPPU and Police; legal enforcement

\section{Abstrak}

Penanganan perkara persaingan usaha tidak sehat oleh Komisi Pengawas Persaingan Usaha (KPPU) tidak dapat berjalan sendiri tanpa bantuan dan dukungan dari lembaga penegak hukum lainnya salah satunya adalah Penyidik Kepolisian. Dukungannya terkait pemanggilan para terlapor, saksi dan saksi ahli, pengumpulan alat bukti dan pemeriksaan yang mengandung unsur tindak pidana hukum persaingan sebagaimana diamanatkan Undang-Undang Nomor 5 Tahun 1999. Masalah yang dikaji dalam penelitian ini adalah, pertama, apakah peran yang dilakukan oleh penyidik kepolisian dalam penegakan hukum persaingan usaha sudah terintegrasi dengan KPPU? kedua, bagaimana integrasi antara KPPU dan penyidik kepolisian dalam penegakan hukum persaingan usaha? Penelitian ini adalah penelitian hukum normatif dengan pendekatan perundang-undangan dan pendekatan kasus. Hasil dari penelitian menyimpulkan peran Penyidik Kepolisian dalam penegakan hukum persaingan usaha dimulai pada saat proses penyelidikan maupun pemeriksaan. KPPU meminta bantuan untuk menghadirkan terlapor, saksi, saksi ahli maupun siapa saja yang terlibat dalam perkara persaingan usaha. Kemudian setelah putusan dikeluarkan oleh KPPU yang tidak diajukan keberatan dapat ditindak lanjuti oleh penyidik apabila memuat aspek pidana. Integrasi antara KPPU dan Penyidik Kepolisian Republik Indonesia diwujudkan dalam bentuk Memorandum of Understanding yang kemudian ditindak lanjuti dengan Kerjasama pembentukan Kelompok Kerja antara KPPU dan Penyidik Kepolisian dalam penanganan perkara persaingan usaha.

Kata-kata Kunci : Integrasi KPPU dan Polri; penegakan hukum; persaingan usaha 


\section{Pendahuluan}

Usia Undang-Undang Nomor 5 Tahun 1999 tentang Larangan Praktek Monopoli dan Persaingan Usaha Tidak Sehat (UU Nomor 5 Tahun 1999) sudah mencapai hampir 21 Tahun dan usia Komisi Pengawas Persaingan Usaha (selanjutnya disebut KPPU) sudah hampir 20 Tahun. KPPU sering kali mengalami kesulitan dan hambatan dalam proses penanganan perkara dalam penegakan hukum. Hambatan tersebut diantaranya pelaku usaha sebagai terlapor yang tidak kooperatif dalam pemeriksaan, tidak mau hadir dan tidak mau menyerahkan dokumen dan alat bukti dalam pemeriksaan maupun dalam persidangan. Sebagai contoh dalam Perkara Nomor 13/KPPU-L/2018 tentang Dugaan Pelanggaran Pasal 22 Undang-Undang Nomor 5 Tahun 1999 Terkait Tender Pekerjaan Pembangunan Jalan Balige By Pass Pada Satker Pelaksanaan Jalan Nasional Wilayah I Provinsi Sumatera Utara. Sidang Perkara Nomor 22/KPPU-L/2019 tentang Pelelangan Umum Paket Kerja Lanjutan Pengembangan Jaringan Air Bersih (Multiyears) Kabupaten Penajam Paser Utara, Kalimantan Timur, APBD Tahun Anggaran 2015-2016. Terhadap 2 contoh perkara di atas, saksi dan terlapor tidak dapat hadir dalam persidangan dan mengajukan reschedule.

Jumlah putusan yang belum dilaksanakan per 31 Desember 2019 sebanyak 90 putusan yang sebagaian besar adalah perkara persekongkolan tender. Jumlah terlapor yang belum menjalankan putusan per 31 Desember 2019 sebanyak 309 terlapor. ${ }^{1}$ Diantaranya terlapor Perkara 04/KPPU-L/2010 Pelelangan Pekerjaan Lanjutan Pembangunan Fasilitas Pelabuhan Laut Takalar DIPA Stimulus Fiskal Tahun Anggaran 2009, Terlapor Perkara No. 18/KPPu-L/2010 Lelang Konstruksi Pembangunan Gedung Asrama Mahasiswa Ma'had Aly UIN Alaudin Makasar 2009, Terlapor Perkara No.11/KPPu-L/2014 Dua Paket Lelang Dinas Pekerjaan Umum Bina Marga Kegiatan Jalan dan Jembatan Pemerintah Kabupaten Ogan Ilir Propinsi Sumatera Selatan, dll. ${ }^{2}$ Sementara KPPU tidak memiliki kewenangan

\footnotetext{
${ }^{1}$ Sumber Komisi Pengawas Persaingan Usaha: Laporan Kinerja 2019, hlm. 39.

2 http://kppu.go.id/blog/2016/02/daftar-terlapor-yang-belum-melaksanakan-putusan-kppu diakses pada 21 Januari 2021.
} 
untuk menyita, menggeledah maupun merampas dokumen yang dapat dijadikan alat bukti dalam proses pemeriksaan.

Berdasarkan ketentuan UU Nomor 5 Tahun 1999 Pasal 36 huruf e bahwa "wewenang komisi memanggil pelaku usaha yang diduga telah melakukan pelanggaran terhadap ketentuan undang-u ndang ini" dan pasal 36 huruf $\mathrm{f}$ Komisi berwenang memanggil dan menghadirkan saksi, saksi ahli, dan setiap orang yang dianggap mengetahui pelanggaran terhadap ketentuan undang-undang ini". ${ }^{3}$

Bagi pelaku usaha yang menolak untuk diperiksa, menolak memberikan informasi yang diperlukan dalam penyelidikan dan atau pemeriksaan, atau menghalangi proses pemeriksaan dapat diserahkan kepada penyidik. Dalam hal ini dapat dilakukan penyidikan sesuai dengan kewenangan sebagaimana ketentuan yang berlaku. Bahkan terhadap putusan komisi yang tidak dilaksanakan dapat menjadi bukti permulaan yang cukup untuk dilakukan penyelidikan.

Berdasarkan ketentuan UU Nomor 5 Tahun 1999 Pasal 36 huruf e bahwa "wewenang komisi memanggil pelaku usaha yang diduga telah melakukan pelanggaran terhadap ketentuan undang-undang ini" dan Pasal 36 huruf f Komisi berwenang memanggil dan menghadirkan saksi, saksi ahli, dan setiap orang yang dianggap mengetahui pelanggaran terhadap ketentuan undang-undang ini"4.

KPPU dalam melaksanakan kewenangannya mengalami beberapa hambatan sebagaimana diuraikan di atas. Untuk membantu dalam melaksanakan kewenangan sebagaimana diamanatkan dalam Pasal 36 huruf e dan $\mathrm{f}$ tersebut KPPU dapat meminta bantuan penyidik. Hal tersebut sebagaimana diatur dalam Pasal 36 huruf g: "meminta bantuan penyidik untuk menghadirkan pelaku usaha. Penyidik yang dimaksud dalam UU Nomor 5 Tahun 1999 adalah penyidik polri sebagaimanana dimaksud dalam KUHAP5. Namun ketentuan tersebut tidak secara otomatis berjalan sebagaimana yang terjadi di Amerika serikat bahwa terjadi hubungan yang harmonis antara Fair Trade Commision (FTC) dengan Departement Criminal of Justice. ${ }^{6}$ Di Indonesia tampaknya tidak semudah yang tertulis dalam UU. Polri tidak dapat melaksanakan tugasnya tanpa adanya

${ }^{3}$ Lihat Pasal 36 huruf e UU No. 5 Tahun1999.

${ }^{4}$ Lihat UU No. 5 Tahun 1999

${ }^{5}$ Lihat Penjelasan dalam Pasal 36 huruf g UU No. 5 Tahun 1999.

6 The Federal Trade Commission, "A Guide to the Federal Trade Commission" www.ftc.gov/bcp/edu/pubs/consumer/general/geno3.shtm, diakses pada tanggal 21 Januari 2021. 
kerjasama dengan KPPU terlebih dahulu yang diwadahi dalam bentuk MoU namun demikian MoU pun tidak cukup dan tidak dapat digunakan untuk menyelesaikan masalah keterlibatan penyidik dalam penanganan perkara persaingan usaha. ${ }^{7}$

Berdasarkan uraian di atas, terlihat bahwa dalam melaksanakan kewenangan sebagaimana diamanatkan UU Nomor 5 Tahun 1999, KPPU tidak dapat hanya menyelesaikan secara sendiri untuk menjalankan penegakan hukum persaingan usaha. Peran penyidik Kepolisian Republik Indonesia cukup penting dalam membantu KPPU dalam proses penegakan hukum persaingan usaha. Tidak menutup kemungkinan perkara persaingan usaha terdapat muatan perkara pidana. Bagi pelaku usaha yang menolak untuk diperiksa, menolak memberikan informasi yang diperlukan dalam penyelidikan dan atau pemeriksaan, atau menghalangi proses pemeriksaan dapat diserahkan kepada penyidik.

Penyidik dalam prakteknya tidak dengan serta merta melaksanakan fungsinya sebagai penyidik sebagaimana dimaksud dalam KUHAP. Ada beberapa alasan mengapa polisi/penyidik tidak bertindak, sementara yang dimaksud penyidik dalam UU Nomor 5/1999 adalah penyidik senbagaimana yang diatur dalam KUHAP yaitu penyidik polisi. Bahkan secara teknis untuk menguatkan integrasi tersebut dibuatlah Mou (Memorandum of Understanding) antara KPPU dengan Polri. Dalam implementasinya Mou tersebut terdapat perbedaan pengaturan terhadap hal-hal yang krusial dalam penanganan perkara dalam persaingan usaha sebagaimanan dimaksud dalam UU Nomor 5 Tahun 1999 dengan penanganan tindak pidana yang diatur dalam KUHAP berdasarkan UU Nomor 8 Tahun 1981.8

Terjadinya perbedaan persepsi dan cara pandang dalam menegakkan Hukum Persaingan usaha diantara penegak hukum tentu akan menimbulkan permasalahan dan tidak adanya kepastian hukum bagi masyarakat. Integrated Competition Justice System belum bisa berjalan secara otomastis dalam proses

\footnotetext{
${ }^{7}$ Wawancara dengan Biro Hukum KPPU RI, Setya Budi Yulianto, 25 Juli 2020.

8Siaran Pers ini disampaikan pada 4 November 2010 oleh Biro Hubungan Masyarakat dan Kerja Sama, Sekretariat Komisi Pengawas Persaingan Usaha.
} 
penegakan perkara persaingan usaha. ${ }^{9}$ Perbedaan tafsir tersebut menjadi isu hukum yang menarik untuk diteliti disebabkan masih minimmnya objek penelitian ini. Terlebih isu perbedaan tafsir akibat kekaburan norma yang tertuang dalam ketentuan UU Nomor 5 Tahun 1999 khususnya terhadap pasalpasal "frasa penyidik", menjadikan penegakan perkara persaingan usaha menjadi tidak optimal.

\section{Rumusan Masalah}

Rumusan masalah yang akan dikaji dalam penelitian ini yaitu, pertama, apakah peran penyidik kepolisian dalam penegakan hukum persaingan usaha sudah berintegrasi dengan KPPU? dan kedua, bagaimana integrasi antara KPPU RI dengan Kepolisian RI dalam penegakan hukum persaingan usaha?

\section{Tujuan Penelitian}

Tujuan dari penelitian ini adalah: pertama, untuk mengetahui dan menganalisis peran dari penyidik kepolisian dalam penegakan hukum persaingan usaha berintegrasi dengan KPPU berdasarkan UU Nomor 5 Tahun 1999. Kedua, untuk menganalisis integrasi yang ideal antara KPPU dan Polri dalam penegakan hukum persaingan usaha.

\section{Metode Penelitian}

Penelitian ini adalah penelitian hukum normatif (normative legal research) yaitu penelitian dengan cara mengkaji peraturan perundang-undangan yang berlaku atau diterapkan pada suatu permasalahan hukum tertentu. Dalam penelitian ini, peraturan yang terkait dengan masalah yang dikaji adalah UU No. 5 Tahun 1999 tentang Larangan Praktek Monopoli dan Persaingan Usaha Tidak Sehat, KUHAP, KUHP, UU No. 2 Tahun 2002 tentang Kepolisian Republik Indonesia, Mou antara KPPU dan Kepolisian Republik Indonesia tentang Penanganan Perkara Persaingan Usaha.

Pendekatan yang dipakai dalam penelitian ini adalah pendekatan perundang-undangan (statuta approach) dan pendekatan kasus terhadap penanganan perkara di KPPU yang membutuhkan kerjasama dengan Penyidik

\footnotetext{
9 Jefons Bawekes, "Integrated Criminal Custice System Terhadap Sistem Peradilan Tindak Pidana Perikanan", ejurnal, Unsrat.a.id., Lex Crimen, Vo. 2 Nomer 7, 2013.
} 
Polri. Pendekatan perundang-undangan dilakukan dengan menelaah semua undang-undang dan regulasi yang bersangkut paut dengan masalah yang diteliti. Bahan hukum primer yaitu bahan hukum yang bersifat autoritatif yaitu yang memiliki otorisasi ${ }^{10}$. Dalam penelitian ini bahan hukum primer terdiri dari: UU Nomor 5 Tahun 1999 tentang Larangan Praktek Monopoli dan Persaingan Usaha Tidak Sehat, terkait pasal-pasal mengenai kewenangan KPPU dan Penyidik Polri; UU Nomor 2 Tahun 2002 tentang Kepolisian Republik Indonesia, terkait pasalpasal tugas dan kewenangan Polri; KUHAP terkait tugas dan kewenanagan Penyidik dan MoU antara KPPU dan Polri. Sedangkan bahan hukum sekunder yaitu semua publikasi tentang hukum yang merupakan dokumen-dokumen resmi yang diperoleh dari: buku-buku literatur bacaan yang berkaitan dengan persaingan usaha dan Kepolisian; hasil-hasil penelitian tentang KPPU dan Polri serta kaitannya dengan persaingan usaha juga artikel-artikel, jurnal-jurnal yang relevan dengan masalah dalam penelitian ini.

Teknik pengumpulan bahan hukum dilakukan dengan cara menggali berbagai informasi yang terkait dengan peraturan perundang-undangan yang menjadi bahan hukum baik primer maupun sekunder. Semua bahan hukum kemudian dikumpulkan dan dikelompokkan sesuai dengan masalah yang dikaji. Semua bahan hukum baik primer maupun sekunder yang sudah terkumpul, sebagaimana dalam penelitian yang sifatnya deskriptif analitis, maka untuk memperoleh hasil penelitian yang mencapai sasaran, analisa bahan hukum dilakukan secara kualitatif untuk selanjutnya ditarik kesimpulan secara induktif.

\section{Hasil Penelitian dan Pembahasan}

\section{Penegakan Hukum Persaingan Usaha Berdasarkan UU Nomor 5 Tahun 1999}

Hakikat penegakan hukum adalah suatu proses untuk mewujudkan keinginan-keinginan hukum menjadi kenyataan. Keinginan-keinginan hukum tersebut tidak lain adalah pikiran-pikiran badan-badan pembuat undang-undang yang dirumuskan dalam peraturan-peraturan itu ${ }^{11}$. Sebelum menguraikan peran hlm. 141.

10 Peter Mahmud Marzuki, Penelitian Hukum, Kencana Perdana Media Group, Edisi Revisi, Jakarta, 2017, 11 Satjipto Rahardjo, Masalah Penegakan Hukum: Suatu Tinjanan Sosiologis, Sinar Baru, Bandung, 2010, hlm. 24. 
penyidik kepolisian dalam penegakan hukum persaingan usaha berdasarkan UU Nomor 5 Tahun 1999 perlu terlebih dahulu dijelaskan mengenai lembaga pengawas dalam persaingan usaha. Pengawasan terhadap persaingan usaha dilakukan oleh sebuah lembaga persaingan usaha yang disebut komisi dalam hal ini adalah KPPU. Pembentukannya didasarkan pada Pasal 34 UU No. 5 Tahun 1999 yang menginstruksikan bahwa pembentukan susunan organisasi, tugas dan fungsi komisi ditetapkan melalui Keputusan Presiden. Komisi ini kemudian dibentuk berdasarkan Keppres Nomor 75 Tahun 199912 dan diberi nama Komisi Pengawas Persaingan Usaha atau KPPU.

Penegakan hukum persaingan usaha berada dalam kewenangan KPPU. Namun demikian, tidak berarti bahwa tidak ada lembaga lain yang berwenang menangani perkara praktek monopoli dan persaingan usaha tidak sehat. Pengadilan Negeri (PN) dan Mahkamah Agung (MA) juga diberi wewenang untuk menyelesaikan perkara tersebut. PN diberi wewenang untuk menangani keberatan terhadap putusan KPPU. Untuk memasuki proses pada persidangan tentunya peran Polri dalam membantu proses penegakan hukum persaingan sangat diperlukan sebagai tersurat pada berbagai pasal di UU Nomor 5 Tahun 1999.13

KPPU mempunyai kewenangan penyelidikan, pemeriksaan, dan memutus perkara serta mengadili dugaan praktek monopoli dan persaingan usaha tidak sehat. Dengan adanya kewenangan KPPU untuk memeriksa dan memutus dugaan praktek monopoli dan persaingan usaha tidak sehat maka Komisi Pengawas Persaingan Usaha merupakan suatu komisi yang menjalankan dan mencakup fungsi eksekutif dan fungsi yudikatif yang tetap mengacu dan berdasar sistem hukum yang berlaku di Republik Indonesia. Dengan kata lain kewenangan tersebut meliputi penyelidikan, penuntutan, konsultasi, memeriksa, mengadili dan memutus perkara. ${ }^{14}$

\footnotetext{
12 Keppres ini kemudian dirubah dengan Peraturan Presiden No. 80 Tahun 2008.

13 Andi Fahmi Lubis, dkk. Hukum Persaingan Usaha, Buku Teks, edisi Kedua, GIZ, KPPU, Jakarta, 2017, hlm. 394.

${ }^{14}$ Lihat Pasal 36 UU No. 5 Tahun 1999 tentang larangan Praktek Monopoli dan Persaingan Usaha Tidak Sehat.
} 
Pada konteks ketatanegaraan, KPPU merupakan lembaga negara komplementer (state auxiliary organ) ${ }^{15}$ yang mempunyai wewenang berdasarkan UU Nomor 5 Tahun 1999 untuk melakukan penegakan hukum persaingan usaha. Secara sederhana state auxiliary organ adalah lembaga negara yang dibentuk diluar konstitusi dan merupakan lembaga yang membantu pelaksanaan tugas lembaga negara pokok (Eksekutif, Legislatif dan Yudikatif) ${ }^{16}$ yang sering juga disebut dengan lembaga independent semu negara (quasi).

KPPU, dalam melaksanakan tugas dan wewenangnya, dapat melakukan beberapa tindakan yang sesuai dengan Undang-Undang Nomor 5 Tahun 1999 yaitu menerima laporan baik dari masyarakat ataupun dari pelaku usaha terkait adanya dugaan praktik monopoli dan/atau persaingan usaha tidak sehat, melakukan penelitian atas laporan tersebut, melakukan pemeriksaan baik pendahuluan maupun lanjutan, memanggil pelaku usaha, saksi, dan ahli, meminta keterangan dari instansi yang terkait hingga melakukan putusan dan menjatuhkan sanksi administrative kepada pelaku usaha yang dinilai melanggar Undang-Undang Nomor 5 Tahun 1999. Hal tersebut secara rinci sebagaimanan diatur dalam pasal 35 dan 36 UU Nomor 5 Tahun 1999. Pasal 35 UU Nomor 5 Tahun 1999 menentukan tugas Komisi meliputi:

a. Melakukan penilaian terhadap perjanjian yang dapat mengakibatkan terjadinya praktek monopoli dan/atau persaingan usaha tidak sehat sebagaimana diatur dalam pasal 4 sampai dengan Pasal 6 .

b. Penilaian terhadap kegiatan usaha dan/atau tin dakan pelaku usaha yang dapat mengakibatkan terjadianya praktek monooli dan atau persaingan usaha tidak sehat sebagaimana diatur dalam Pasal 17 sampai dengan Pasal 24;

c. Melakukan penilaian terhadap ada atau tidak adanya penyalahgunaan posisi dominan yang dapat mengakibatkan terjadinya praktek monopoli dan/atau persaingan usaha tidak sehat sebagaiamana diatur dalam Pasal 25 sampai dengann Pasal 28;

d. Mengambil tindakan sesuai dengan wewenang komisi sebagaimana diatur dalam Pasal 36;

e. Memberikan saran dan pertimbangan terhadp kebijakan poemerintah yang berkaitan dengan praktek monopoli dan atau persaingan usaha tidak sehat;

${ }^{15}$ Budi L Kagramanto, “Implementasi UU No. 5 Tahun 1999 oleh KPPU”, Jurnal Ilmu Hukum Yustisia, 2007, hlm. 2. hlm. 24.

${ }^{16}$ Jimly Asshiddiqie, "Perkembangan dan Konsolidasi Lembaga Negara Pasca Reformasi”, Konpress, 2006, 
f. Menyusun pedoman dan atau publikasi yang berkaiyan dengan Undangundang ini;

g. Memberikan laporan secara berkala atas hasil kerja komisi kepad Presiden dan Dewan Perwakilan Rakyat.

Adapun wewenang KPPU diatur dalam Pasal 36 UU Nomor 5 Tahun 1999:

a. Menerima laporan dari masyarakat dan atau dari pelaku suaha tentang dugaan terjadinya prqaktek monopoli dan atau persaingan usaha tidak sehat;

b. Melakukan penelitian tentang dugaan adanya kegiatan usaha dan atau Tindakan pelaku usaha yang dapat mengakibatkan terjadinya praktek monopoli dan atau persaingan usaha tidak sehat;

c. Melakukan penyelidikan dan atau pemeriksaan terhadap kasus dugaan praktek monopoli dan atau persaingan usaha tidk sehat yang dilaporkan oleh masyarakat atau oleh pelaku usaha atau yang ditemukan oleh kkomisi sebagai hasil dari penelitiannya;

d. Menyimpulkan dai hasil penyelidikan dan atau pemeriksaan tentang ada atau tidak adanya praktek monopoli dan atau prsaingan usaha tidak sehat;

e. Memanggil pelaku usaha yang diduga telah melakukan pelanggaran terhadap ketentuan undang-undang ini;

f. Memanggil dan menghadirkan saksi-saksi ahli dan setiap orang yang dianggap mengetahui pelanggaran terhadap ketentuan undang-undang ini;

g. Meminta bantuan penyidik untuk menghadirkan pelaku usaha, saksi, saksi ahli atau setiap orang sebagaimana dimaksud huruf e dan huruf $f$, yang tidak bersedia memenuhi panggilan komisi;

h. Meminta keterangan dari instansi pemerintah dalam kaitannya dengan penyelidikan dan atau pemeriksaan terhadp pelaku usaha yang melanggar ketentuan undang-undang ini;

i. Mendapatkan, meneliti, dan atau menilai surat, dokumenatau alat bukti lain guna penyelidikan dan atau pemeriksaan;

j. Memutuskan dan menetapkan ada atau tidak adanya kerugian di pihak pelaku usaha lain atau masyarakat;

k. Memberitahukan putusan Komisi nkepad pelaku usaha yang diduga melakukan praktek monopoli dan atau persainga usaha tidak sehat;

1. Menjatuhkan sanksi berupa Tindakan administrasi kepada pelku usah yang melanggar ketentuan undng-undang ini.

Wewenang KPPU demikian luas yang meliputi investigative, authority, enforcement, authority dan litigating authority, namun dalam perjalanannya telah memunculkan sejumlah kontroversial dan menimbulkan polemik baru, khususnya mengenai hubungan institusional dengan Lembaga Kepolisian sebagai institusi yang memiliki kewenangan untuk melakukan penyelidikan dan 
penyidikan. Penyatuan semua wewenang tersebut pada KPPU bermasalah. Hal ini tidak sesuai dengan prinsip tata kelola pemerintahan yang baik. Paling tidak KPPU harus memisahkan ketiga fungsi ini secara internal. Caranya, komisioner yang terlibat dalam proses penyidikan tidak boleh ikut dalam proses penuntutan. Komisioner yang menangani penuntutan tidak boleh menjadi majelis komisi yang memutus perkara tersebut.

Untuk itu perlu kiranya dilihat aktifitas proses dan prosedur penegakan hukum yang ada di KPPU berdasarkan UU No. 5 Tahun 1999. Hal tersebut terkait dengan Hukum Acara yang berlaku di KPPU. Hukum Acara di KPPU ditetapkan oleh KPPU sebagaimana amanat dari Pasal 35 huruf UU No. 5 Tahun 1999 bahwa KPPU berwenang membuat pedoman atau publikasi yang terkait dengan undang-undang ini. Perlu diketahui bahwa Hukum acara Persaingan Usaha amat sangat sumir diatur dalam UU Nomor 5 Tahun 1999 yaitu hanya diatur dalam Pasal 38 sampai dengan Pasal 44. Sebagaimana yang sudah diuraikan dalam tugas dan wewenang di atas, maka secara garis besar dalam konteks penegakan hukum KPPU memliki kewenangan mulai dari penyelidikan, pemeriksaan, sampai memutus perkara dan menjatuhkan sanksi administratif terhadap pihak yang dinyatakan terbukti melanggar UU Nomor 5 Tahun 1999.

Salah satu wewenang KPPU adalah menggali informasi yang terkait dengan laporan yang sedang diperiksa dari pihak-pihak yang dianggap mengetahui dan terlibat dalam perkara yang bersangkutan. Pihak-pihak itu antara lain pelaku usaha baik terlapor maupun pelapor, keterangan saksi dan ahli maupun dari hasil dokumen-dokumen yang diserahkan pada saat pendaftaran perkara. Dalam proses pemanggilan pelaku usaha, saksi dan ahli untuk dimintai keterangannya pada pemeriksaan, Komisi Pengawas Persaingan Usaha melalui investigatornya sering kali mengalami kesulitan dan hambatan dalam menghadirkan dalam proses pemeriksaan di KPPU. Hal tersebut tentu akan mempengaruhi kualitas putusan. Sementara KPPU tidak boileh memutus in absentia dengan kata lain semua pihak yang berperkara harus dapat dihadirkan dalam proses pemeriksaan.

Hal tersebut di atas sebagaimana diatur dalam ketentuan UU Nomor 5 Tahun 1999 Pasal 36 huruf e bahwa “wewenang komisi memanggil pelaku usaha 
yang diduga telah melakukan pelanggaran terhadap ketentuan undang-undang ini" dan 36 huruf $\mathrm{f}$ Komisi berwenang memanggil dan menghadirkan saksi, saksi ahli, dan setiap orang yang dianggap mengetahui pelanggaran terhadap ketentuan undang-undang ini"17.

\section{Peran Kepolisian Republik Indonesia (Polri) dalam Penegakan Hukum Persaingan Usaha Berdasarkan UU Nomor 5 Tahun 1999}

Kerjasama antara lembaga lain seperti kepolisian, pengadilan dan lainlainnya sangat dibutuhkan dalam penanganan perkara persaingan usaha. Kesulitan yang dialami KPPU dalam menghadirkan terlapor, saksi dan/atau ahli serta sulitnya untuk para pihak untuk menyerahkan dokumen dalam proses pemeriksaan, maka disitulah peran Polisi sangat dibutuhkan dalam upaya untuk membantu proses penegakan hukum. Secara tegas peran serta atau integrasi antara KPPU dan Kepolisian sebagaimana yang diatur dalam lingkup yang ada dalam UU Nomor 5 Tahun 1999 tentang Larangan Praktek Monopoli dan Persaingan Usaha Tidak Sehat, yang akan diuraikain di bawah ini.

Peran pertama dari kepolisian sebagaimana tertuang dalam Pasal 36 huruf g UU No. 5 Tahun 1999 menyebutkan bahwa: "Dalam menjalankan tugas-tugasnya KPPU untuk: "meminta bantuan penyidik untuk menghadirkan saksi, saksi ahli, dan setiap orang yang dianggap mengetahui pelanggaran ketentuan UU Nomor 5 Tahun 1999 yang tidak bersedia memenuhi panggilan Komisi"18.

Berdasarkan ketentuan pasal tersebut, KPPU dalam hal melaksanakan tugas melakukan pengawasan persaingan usaha dapat meminta bantuan kepada penyidik untuk menghadirkan saksi, saksi ahli dan siapaun yang terlibat dan mengetahui adanya pelanggaran terhadap UU Nomor 5 Tahun 1999. Permintaan bantuan tersebut dalam hal mereka yang dipanggil dan dimintai keterangan tidak bersedia memenuhi panggilan dari KPPU. Dalam ketentuan pasal tersebut tertulis frase "penyidik", penyidik yang dimaksud dalam ketentuan tersebut adalah penyidik kepolisian sebagaimana yang dimaksud dalm UU Nomor 8 Tahun 1981 tentang $\mathrm{KUHAP}^{19}$. Kehadiran para pihak dalam proses pemeriksaan sangat

\footnotetext{
${ }^{17}$ Lihat Ketentuan Pasal 36 huruf f UU No. 5 Tahun 1999.

${ }^{18}$ Lihat Ketentuan Pasal 36 huruf g UU No. 5 Tahun 1999.

${ }^{19}$ Lihat Penjelasan Pasal 36 huruf g UU No. 5 Tahun 1999.
} 
penting, mengingat KPPU tidak memiliki kewenangan untuk memaksa seseorang dalam pemeriksaan, maka bantuan penyidik sangat diperlukan.

1) Pasal 41 ayat (3)

Peran Polri dalam proses penegakan hukum persaingan usaha juga termasuk ketika pelaku usaha menolak untuk diperiksa, menolak memberikan informasi yang diperlukan dalam penyelidikan dan atau pemeriksaaan, atau menghambat proses penyelidikan dan atau pemeriksaan ${ }^{20}$. Penolakan terhadap proses penyelidikan maupun pemeriksaan yang dilakukan oleh KPPU dapat dikategorikan sebagai tindak pidana (Lihat Pasat $261 \mathrm{KUHP}$ ). Apabila ketentuan tersebut dilanggar oleh pelaku usaha (terlapor) maka KPPU menyerahkan kepada penyidik untuk dilakukan penyidikan sesuai dengan ketentuan yang berlaku (Pasal 41 ayat (3). Berdasarkan penjelasan Pasal 41 ayat (3) tersebut yang diserahkan oleh komisi kepada penyidik untuk dilakukan penyidikan tidak hanya perbuatan atau tindak pidana sebagaimana dimaksud ayat (2), tetapi juga termasuk pokok perkara yang sedang diselidiki dan diperiksa oleh Komisi. Sehingga berdasarkan penjelasan pasal tersebut maka perkara beralih menjadi perkara pidana dan sepenuhnya diserahkan kepada Polisi untuk melakukan proses lebih lanjut sesuai dengan kewenangan sebagaimana peraturan perundangan yang berlaku.

2) Pasal 44 ayat (5)

Peran selanjutnya yang dimiliki oleh penyidik Polri dalam perkara persaingan usaha adalah sebagaimana yang diatur dalam pasal 44 ayat (5) UU No. 5 tahun 1999 bahwa: "Putusan Komisi sebagaimana dimaksud dalam Pasal 43 ayat (4) merupakan bukti permulaan yang cukup bagi penyidik untuk melakukan penyidikan. Hal tersebut tentunya mengacu pada ketentuan Pasal 43 (4) bahwa putusan yang dimaksud adalah putusan yang sudah memiliki kekuatan hukum tetap di tingkat KPPU dan tidak diajukan keberatan maupun diajukan kasasi. Hal tersebut mengacu pada ketentuan Pasal 44 ayat (4) bahwa KPPU akan menyerahkan pelanggaran terhadap tidak dilaksanakannya putusan KPPU oleh pelaku usaha dan tidak mengajukan keberatan dan tidak mematuhi putusan KPPU. Perihal yang harus ditindak lanjuti oleh penyidik (Polri) adalah putusan KPPU yang di dalamnya mengandung unsur pidana.

Berdasarkan ketentuan Pasal 216 KUH Pidana dinyatakan bahwa:

(1)Barang siapa dengan sengaja tidak menuruti perintah atau permintaan yang dilakukan menurut UU oleh pejabat yang tugasnya mengawasi sesuatu atau oleh pejabat berdasarkan tugasnya demikian pula yang diberi kuasa untuk mengusut atau memeriksa tindak pidana: demikian pula barang siapa dengans engaja mencegah menghalang-halangi atau menggagalkan tindakan guna menjalankan ketentuan UU yang dilakukan

${ }^{20}$ Lihat ketentuan Pasal 41 ayat (2) UU No. 5 Tahun 1999. 
oleh salah seorang pejabat tersebut diancam dengan pidana penjara paling lama 4 bulan 2 minggu atau pidana denda paling banyak 9 ribu rupiah.

(2)Disamakan dengan pejabat tersebut di atas setiap orang yang menurut ketentuan UU terus menerus atau untuk sementara waktu diserahi tugas menjalankan jabatan umum.

(3)Jika pada waktu melakukan kejahatan belum lewat 2 tahun sejak adanya pemidanaan semacam itu juga maka pidananya dapat bertambah sepertiga.

Penjelasan dari pasal tersebut adalah adanya unsur barang siapa, dengan sengaja, tidak menuruti perintah atau permintaan yang dilakukan menurut UU dan unsur lainnya adalah: (a) barang siapa; (b) sengaja mencegah menghalanghalangi, menggagalkan tindakan guna menjalankan UU dan (c) dilakukan pejabat.

Ketentuan Pasal 216 ayat (1) KUHP tersebut ditujukan kepada orang yang melakukan perbuatan dengan sengaja (artinya dia sadar melakukannya) tidak menuruti ataupun mengabaikan permintaan dari UU dapat dihukum paling lama 4 bulan 2 minggu. Pasal yang sama juga memuat, bagi orang yang sengaja melakukan pencegahan, menghalang-halangi pejabat dalam menjalankan perintah UU dikenakan hukuman yang sama. Berdasarkan ketentuan Pasal 216 KUH Pidana tersebut di atas maka Polri dapat melaksanakan kewenangannya, apabila para pihak yang dijatuhi sanksi oleh KPPU tidak dengan sukarela maupun setelah melalui proses fiat eksekusi ke Pengadilan tidak melaksanakan putusan KPPU. Artinya para pihak (terlapor) melakukan pembangkangan terhadap putusan pejabat publik dalam hal ini KPPU.

Bila dikaitkan dengan peran Polri dalam penegakan Hukum persaingan Usaha tampak bahwa antara Polri dan KPPU sama-sama diberi kewenangan oleh undang-undang sesuai dengan tugas dan kewenangan berdasarkan UU Nomor 5 Tahun 1999. Polri sebagai penyidik diberikan kewenangan oleh UU Nomor 5 Tahun 1999 untuk membantu KPPU dalam upaya penegakan hukum persaingan.

Sesuai dengan teori kewenangan, dibedakan menjadi dua yaitu wewenang personal dan ofisial. Menurut Philipus M. Hadjon, ada tiga sumber bagi badan 
atau pejabat tata usaha Negara dalam memperoleh kewenangan yaitu atribusi, delegasi dan mandate. ${ }^{21}$

"Kewenangan atribusi dalam hal ada pengakuan hak atas suatu kewenangan yang baru. Dalam delegasi ada pengalih tanganan dari suatu kewenangan yang ada. Untuk atribusi dan delegasii kewenangan membuat keputusan harus didasarkan pada suatu undang-undang formal. Dalam hal tertentu seorang pegawai memperoleh kewenangan untuk membuat keputusan atas nama penguasa, hal ini disebut mandate, dimana tidak ada pengakuan kewenangan, hanya menyangkut janji kerja interen antara penguasa dan pegawainya. Sedangkan dalam hal delegasi pejabat yang memperoleh delegasi bertanggung jawab sendiri atas keputusan yang dibuatnya, sedangkan untuk mandate, keputusan yang dibuat penerima mandat adalah atas nama dan tanggung jawab pemberii mandat".

Dari uraian di atas jelaslah bahwa wewenang atribusi merupakan wewenang yang melekat pada jabatan, dengan perkataan lain wewenang dibentuk bersama dengan jabatan tersebut. Oleh karena itu setiap wewenang yang timbul dari atribusi akan melahirkan wewenang yang sifatnya asli. Menurut SF Marbun22, wewenang adalah kemampuan untuk melakukan suatu tindakan hukum publik (yuridis), juga sebagai kemampuan bertindak yang diberikan undang-undang untuk melakukan hubungan hukum. Menurut Prajudi Atmosudirjo 23 , wewenang adalah kekuasaan untuk melakukan suatu tindakan hukum publik, sedangkan Indroarto ${ }^{24}$, wewenang adalah kemampuan yang diberikan oleh peraturan perundang-undangan yang menimbulkan akibatakibat hukum.

Terdapat dua macam ketentuan sanksi yang diatur dalam Undang Undang Nomor 5 Tahun 1999 tentang Larangan Praktek Monopoli Dan Persaingan Usaha Tidak Sehat. Sanksi yang berupa administrative dan sanksi pidana pokok dan tambahan. Sanksi administrative sebagaimana diatur dalam Pasal 47 dapat berupa: 25

1. Penetapan pembatalan perjanjian.

${ }^{21}$ Philipus M. Hadjon, dkk., Pengantar Hukum Administrasi Indonesia The Introduction of Administrative Law, Gajah Mada University Press,Jogyakarta, 2017, hlm. 137.

22 SF. Marbun, Op. Cit., hlm. 154.

${ }^{23}$ Prajudi Atmosudirjo, Hukum Administrasi Negara, Bhakti Indonesia, Jakarta, 2009, hlm. 76.

${ }^{24}$ Indroarto, Usaha Memahami Undang-Undang tentang Peradillan tata Usaha Negara, Edisi Baru, Pustaka Sinar Harapan, Jakarta, 2016, hlm. 177.

${ }^{25}$ Lihat Pasal 47 UU No. 5 Tahun 1999. 
2. Perintah kepada pelaku usaha untuk menghentikan integrasi vertical.

3. Perintah kepada pelaku usaha untuk menghentikan kegiatan yang terbukti menimbulkan praktek monopoli dan persaingan usaha tidak sehat dan khususnya merugikan masyarakat.

4. Perintah kepada pelaku usaha untuk menghentikan penyalah gunaan posisi dominan.

5. Penetapan pembatalan atau penggabungan atau peleburan badan usaha dan pengambil alihan saham.

6. Penetapan pembayaran ganti rugi.

7. Pengenaan denda serendah-rendahnya Rp. 1.000.000.000,00 dan setinggitingginya Rp. 25.000.000.000,00.

Sedangkan yang berupa sanksi pidana pokok sebagaimana diatur dalam Pasal 48 tentang pengenaan denda atau kurungan sebagai pengganti denda dengan besaran rupiah tertentu seperti yang tertuang dalam Pasal 48 tersebut. Dukungan dan bantuan dari Polri menjadikan proses penanganan perkara dapat lebih cepat dan efisien baik dari segi waktu, biaya, dan tenaga. Hal ini sematamata untuk memberikan kepastian hukum dan kredibilitas lembaga di depan masyarakat pada umumnya dan para pelaku usaha pada khususnya.

Dengan demikian maka peran penyidik Polri dalam penegakan hukum persaingan usaha berdasarkan UU Nomor 5 Tahun 1999 sebagai berikut:

1. Pasal 36 huruf g : meminta bantuan penyidik untuk menghadirkan sakasi, saksi ahli dan setiap orang yang dianggap mengetahui penggaran ketentuan UU Nomor 5 Tahun 1999

2. Putusan Komisi sebagaimna dimaksud dalam Pasal 43 ayat (4) merupakan bukti permulaan yang cukup bagi penyidik untuk melakukan penyidikan.

3. Pasal 44 ayat (4) bahwa KPPU akan menyerahkan pelanggaran terhadap tidak dilaksanakannya putusan KPPU oleh pelaku usaha dan tidak mengajukan keberatan dan tidak mematuhi putusan KPPU.

4. Pasal 48 ayat (3) pelanggaran terhadap ketentuan Pasal 41 akan dikenai sanksi pidana pokok.

5. Pasal 49 pengenaan sanksi pidana tambahan. ${ }^{26}$

\section{Bentuk Integrasi KPPU RI dan Penyidik Kepolisian dalam Penegakan Perkara Persaingan Usaha}

Integrasi mempunyai arti pembauran atau penyatuan darin unsur-unsur yang berbeda sehingga menjadi kesatuan yang utuh atau bulat. ${ }^{27}$ Integrasi

\footnotetext{
${ }^{26}$ Pasal 49 dicabut dan dinyatakan tidak berlaku berdasrkan UU No. 11 Tahun 2020 tentang Cipta Kerja.

${ }^{27}$ Kamus Besar Bahasa Indonesia, Balai Pustaka, Jakarta, 2007, hlm. 437.
} 
merujuk pada bersatu padunya semua Lembaga hukum di negara ini dalam menegakkan Hukum Persaingan Usaha. Penegakan Hukum Persaingan Usaha menurut UU No. 5 Tahun 1999 harus dilakukan secara integratif. Karena itu meski KPPU memiliki kewenangan penuh bahkan dianggap sebagai Lembaga "super body", KPPU tetap berada pada bingkai system hukum nasional. KPPU tidak bisa berjalan sendiri, membutuhkan bantuan dan Kerjasama dari penegak hukum lainnya seperti pihak penyidik Kepolisian sebagaimana yang dimaksud dalam UU Nomor 5 Tahun 1999.28

Tugas pokok Kepolisian Republik Indonesia sebagaimana yang tercantum dalam Pasal 13 UU Nomor 2 Tahun 2002 adalah memelihara keamanan dan ketertiban masyarakat, menegakkan hukum, dan memberikan perlindungan, pengayoman, dan pelayanan kepada masyarakat. Disebutkan dengan jelas bahwa salah satu tugas kepolisian adalah menegakkan hukum, termasuk didalamya adalah hukum persaingan usaha yang dikawal oleh Komisi Pengawas Persaingan Usaha. Dijelaskan lebih detail dalam Pasal 14 UU Nomor 2 Tahun 2002 bahwa polisi dapat melakukan penyelidikan dan penyidikan tentang segala hal yang memenuhi unsur tindak pidana sesuai dengan ketentuan Kitab Undang Undang Hukum Pidana dan peraturan perundang- undangan yang lainnya. Berdasarkan ketentuan pasal tersebut maka polisi dapat melakukan penyelidikan dan penyidikan terhadap pelanggaran UU Nomor 5 Tahun 1999 apabila diperintahkan. Dalam kaitannya dengan kerjasama yang dilakukan bersama KPPU, kepolisian dapat membantu investigator KPPU terhadap perkara praktek monopoli dan persaingan usaha tidak sehat yang mengandung unsur pidana.

Terhadap perkara-perkara yang bersumber dari pelanggaran UU Nomor 5 Tahun 1999 yang tentunya memuat unsur pidana maka penyidik Polri dapat menggunakan landasan hukum berdasarkan Kitab Undang-Undang Hukum Pidana (KUHP) untuk hukum materiilnya dan Kitab Hukum Acara Pidana (KUHAP) untuk hukum formilnya jo UU Nomor 5 Tahun 1999. Pada sanksi pidana sebagaimana diatur dalam Pasal 48 UU Nomor 5 Tahun 1999, mengenai pidana pokok merupakan kewenangan dari kepolisian.

${ }^{28}$ Rai Mantili, dkk, "Problematika Penegakan Hukum Persaingan Usaba Di Indonesia Dalam Rangka Menciptakan Kepastian Hukum”, Padjadjaran, Jurnal Ilmu Hukum Volume 3 Nomor 1 Tahun 2016. 
Pasal 48 UU Nomor 5 Tahun 1999 menentukan bahwa sanksi pidana pokok meliputi pidana denda minimal Rp. 25.000.000.000,00 dan maksimal Rp. 100.000.000.000,00. Pidana denda tersebut dapat diganti dengan pidana kurungan selama-lamanya 6 bulan. Sanksi pidana ini diberikan oleh pengadilan (bukan merupakan kewenangan KPPU) apabila:

1) Terjadi pelanggaran terhadap ketentuan Pasal 4, 9-14, 16-19, 25,27, dan 28, pelaku diancam dengan pidna serendah-rendahnya Rp. 25.000.000.000,00 dan setinggi-tingginya Rp. 100.000.000.000,00 atau pidana kurungan pengganti denda selama-lamanya 6 bulan.

2) Terjadi pelanggaran terhadap ketentuan Pasal 5-8, 15, 20-24 dan 26. Pelaku diancam pidana denda serendah-rendahnya Rp. 5.000.000.000,00 dan setinggitingginya Rp. 25.000.000.000,00 atau pidana kurungan pengganti denda selama lamanya 5 bulan.

3) Terjadi pelanggaran terhadap ketentuan Pasal 41. Ancaman pidananya adalah serendah rendahnya Rp. 1.000.000.000,00 dan setinggi-tingginya Rp. 5.000.000.000,00 atau pidana kurungan pengganti denda selama-lamanya 3 bulan.

Jelas bahwa apabila pelaku usaha tidak bersedia menyerahkan alat bukti baik dalam penyelidikan maupun pemeriksaan serta menolak untuk diperiksa, menolak menyampaikan informasi yang diperiksa dalam penyelidikan dan/atau pemeriksaan atau menghambat jalannya penyelidikan dan pemeriksaan dapat dikenakan sanksi pidana pokok sebagaimana diatur pada Pasal 48 ayat (3) UU Nomor 5/1999.

Di dalam penjelasan umum UU Nomor 5/1999 disebutkan bahwa Komisi hanya berwenang menjatuhkan sanksi administrative, sedangkan yang berwenang menjatuhkan sanksi pidana adalah pengadilan. Untuk dapat menjatuhkan sanksi pidana tentunya harus dimulai dari proses penyelidikan dan penyidikan yang dilakukan oleh polisi. Suatu perkara yang ditangani oleh KPPU dapat diserahkan kepada penyidik dan karenanya dapat dijatuhi pidana bila dalam hal:

1) Pelaku usaha tidak menjalankan putusan Komisi yang berupa sanksi administrative (Pasal 44 ayat (4)). 
2) Pelaku usaha menolak untuk diperiksa, menolak memberikan informasi yang diperlukan dalam penyelidikan dan atau pemeriksaan, atau menghambat proses penyelidikan dan atau pemeriksaan (Pasal 41 ayat (2)).

Terhadap kedua pelanggaran tersebut, Komisi menyerahkan kepada penyidik untuk dilakukan penyidikan. Putusan Komisi merupakan bukti permulaan yang cukup bagi penyidik untuk melakukan penyidikan (Pasal 41 ayat (3)) jo Pasal 44 ayat (5).

Dengan adanya penandatanganan kerjasama antara KPPU dengan Polri, maka diharapkan adanya kerjasama dan koordinasi antara KPPU dan Polri dalam hal penanganan dugaan praktik monopoli dan persaingan usaha tidak sehat sesuai dengan kapasitas dan kewenangan masing-masing lembaga dan penanganan perkara yang lebih efektif, efisien dan cepat dalam rangka penegakan hukum persaingan usaha.

Berdasarkan teori kewenangan jelaslah bahwa wewenang yang dimiliki oleh KPPU dan Polri dalam penegakan Hukum Persaingan adalah kewenangan atribusi, yaitu merupakan wewenang yang melekat pada jabatan, dengan perkataan lain wewenang dibentuk bersama dengan jabatan tersebut. Oleh karena itu setiap wewenang yang timbul dari atribusii akan melahirkan wewenang yang sifatnya asli. Menurut SF Marbun, wewenang adalah kemampuan untuk melakukan suatu tindakan hukum publik (yuridis), juga sebagai kemampuan bertindak yang diberikan undang-undang untuk melakukan hubungan hukum. Menurut Prajudi Atmosudirjo29, wewenang adalah kekuasaan untuk melakukan suatu tindakan hukum publik, sedangkan Indroarto ${ }^{30}$, wewenang adalah kemampuan yang diberikan oleh peraturan perundang-undangan yang menimbulkan akibat-akibat hukum.

Bila dikaitkan dengan peran Polri dalam penegakan Hukum persaingan Usaha tampak bahwa antara Polri dan KPPU sama-sama diberi kewenangan oleh undang-Undang sesuai dengan tugas dan kewenangan berdasarkan UU Nomor 5 Tahun 1999. Polri sebagai penyidik diberikan kewenangan oleh UU Nomor 5 Tahun 1999 untuk membantu KPPU dalam upaya penegakan hukum persaingan.

\footnotetext{
29 Prajudi Atmosudirjo, Ibid.

${ }^{30}$ Indroarto, Loc. Cit.
} 
Untuk mewujudkan integrasi dan Kerjasama antara KPPU dengan Polri maka dibuatlah Memorandum of Understanding (MoU) sebagai upaya untuk implementasi dari pasal-pasal dalam UU yang terkait dengan peran Polri dalam penegakan Hukum Persaingan Usaha.

MoU dilakukan sejak 2009 yang kemudian diperbaharui pada 2015. Maksud dari MoU adalah sebagai pedoman bagi para pihak dalam ramgka kerja sama penanganan dugaan perkara praktik monopoli dan persaingan usaha tidak sehat dan untuk mewujudkan sinergitas dalam rangka kerja sama penanganan perkara dugaan praktik monopoli dan persaingan suaha tidsak sehat.

Kerja sama meliputi pembinaan intelijen ekonomi, menghadirkan para pihak termasuk pelaku, saksi, dan saksi ahli serta barang bukti dan kerja sama tukar menukar informasi. Kerjasama tersebut juga merupakan bentuk implementasi penegakan hukum sebagai satu kesatuan yang terintegrasi (integrated competition justice system). Integrasi penegakan hukum persaingan usaha pada intinya tidak semata-mata hanya untuk penegakan hukum. Integrasi dimaksudkan adalah kepentingan masyarakat melalui penegakan hukum yang tentunya sesuai dengan koridor masing-masing. ${ }^{31}$

Kerjasama antara KPPU dan Polri sepakat untuk melakukan tiga hal penting secara bersama-sama. ${ }^{32}$ Pertama, terkait pembinaan yang meliputi pengembangan intelijen ekonomi dan pelatihan penanganan perkara praktek monopoli dan/atau persaingan usaha tidak sehat. Kedua, kesepakatan untuk bekerjasama dalam pelaksanaan operasional penangannan perkara yang dimaksud. Ruang lingkup bantuannya meliputi bantuan kepada KPPU untuk menghadirkan para pihak terkait penanganan perkara seperti terlapor, saksi, saksi ahli dan siapapun yang terlibat dalam perkara praktek monopoli dan/atau persaingan usaha tidak sehat. Selanjutkan akan ada penyerahan dokumen dan perkara tindak pidana hukum persaingan usaha serta penyerahan putusan KPPU terkait praktek monopoli dan/atau persaingan usaha tidak sehat sebagai bukti permulaan yang cukup bagi penyidik untuk melakukan penyidikan. Selain itu, untuk operasional, ketiga lembaga sepakat untuk bersama saling membantu mengamankan dan mengawal

31 Mohammad Reza, "Kerjasama KPPU dengan Penyidik Dalam Penanganan Tindak Pidana Hukum Persaingan Usaha”, Jurnal Persaingan Usaha, KPPU, Edisi 5, Jakarta, 2011.

32 Nota Kesepamaman KPPU-Polri, 8 Oktober 2010. 
penanganan perkara-perkara monopoli dan persaingan usaha tidak sehat yang didapati terjadi. Untuk itu akan ada kerjasama penyelidikan intelijen dan penugasan penyelidik dan atau penyidik Polri dalam hal penyelidikan dan pemeriksaan di KPPU. Pada naskah kerjasama, kedua lembaga juga sepakat untuk saling tukar menukar informasi dibidang informasi yang terkait dengan laporan dan atau bantuan dari setiap orang atau badan hikum mengenai dugaan tindak pidana hukum persaingan, saling tukar-menukar informasi yang berkaitan dengan kepentingan penyelidikan dan penyidikan tindak pidana hukum persaingan usaha tersebut, dan yang saling tukar-menukar informasi yang berkaitan dengan dugaan praktek monopoli dan praktek usaha yang tidak sehat.

Tindak lanjut dari MoU dibentuk kelompok kerja baik dari Polri maupun KPPU terkait penanganan tindak pidana itu. Kelompok kerja tersebut bertugas untuk merumuskan secara teknis bagaimana operasional kerjasama tersebut. "Misalnya tukar-menukar informasi dari kajian ekonomi itu bagamana? Apakah dengan adanya MoU ini pelaku praktek monopoli bisa dipidana? Selama ini, kerjasama kedua lembaga untuk bahu-membahu mengantisipasi dan menindak para pengusaha yang melanggar sudah terjalin sejak lama, tetapi masih ada kendala dengan adanya MoU ini, jika ada orang yang dipanggil untuk diperiksa dan dimintai keterangan terkait pelanggaran persaingan usaha tidak sehat tidak mau hadir.

“Bagi KPPU, kerjasama tersebut merupakan momentum untuk menjadikan lembaga persaingan usaha sebagai lembaga yang efektif, efisien dan kredibel dalam penegakan hukum dan penciptaan iklim persaingan usaha yang sehat di tanah air". Sebagai sebuah lembaga "pengawas undang-undang" KPPU memiliki keterbatasan kewenangan mulai dari pembuktian, pemanggilan para pihak, eksekusi putusan, dan penjatuhan sanksi pidana. KPPU tidak memiliki daya paksa sebagaimana Lembaga peradilan, jaksa, maupun polisi, namun demikian undang-undang telah memberikan kewenangan yang begitu besar pada Lembaga tersebut.

Penegakan hukum merupakan rangkaian proses untuk menjabarkan adanya sebuah ide, nilai dan cita hukum dalam mencapai suatu tujuan hukum tiga pilar 
dalam mewujudkan kepastian hukum dapat dibagi menjadi kepastian dalam bentuk peraturan perundang-undangan, pranata hukum dan lembaga. Terciptanya sebuah kepastian hukum syarat yang harus dipenuhi adalah adanya peraturan perundangan yang jelas. Peraturan yang ada saat ini yaitu UU Nomor 5 Tahun 1999 terkait dengan ketentuan penegakan hukum persaingan usaha menimbulkan multitafsir33, diantaranya terkait dengan permasalahan kewenangan KPPU dalam meminta bantuan penyidik sebagaimana diatur dalam Passl 36 huruf g UU Nomor 5 Tahun 1999, secara praktek tidak bisa berjalan. Hal tersebut terjadinya perbedaan tafsir dalam memaknai bunyi dari pasal tersebut. Bagi pihak kepolisian bahwa proses penegakan hukum berdasarkan UU Nomor 5 Tahun 1999 sepenuhnya kewenangan KPPU namun di satu sisi ada kewenangan Lembaga lain dalam hal ini adalah penyidik kepoilisian sebagaimana dimaksud dalam KUHAP sehingga menimbulkan tafsir yang berbeda dalam pelaksanannya.

Untuk itulah dibutuhkan adanya harmonisasi hukum dari hasil MoU antara Polri dengan KPPU yaitu perubahan terhadap UU Nomor 5 Tahun 1999 dan UU Nomor 8 Tahun 1981 tentang KUHAP dimana Competition Integrated Justice System diatur secara jelas sehingga dapat dijalankan. Kepastian hukum merupakan salah satu unsur yang tak tergantikan demi terciptanya keadilan di mata hukum. Tujuannya untuk membangun kepercayaan masyarakat terhadap hukum sekaligus mendorong adanya kesadaran masyarakat untuk patuh dan tunduk pada hukum.

Hukum bertujuan untuk mewujudkan kepastian dalam hubungan antar manusia dalam masyarakat, yaitu menjamin prediktabilitas, dan juga bertujuan untuk mencegah bahwa hak yang terkuat yang berlaku, beberapa asas yang terkandung dalam asas kepastian hukum adalah: ${ }^{34}$

a. Asas legalitas, konstitusionalitas dan supremasi hukum;

b. Asas-asas undang-undang menetapkan berbagai perangkat aturan tentang cara pemerintah dan para pejabatnya melakukan Tindakan pemerintahan;

c. Asas no-retroaktif perundang-undangan: sebelum mengikat perundanbgundangan harus diumumkan secara layak;

${ }_{33}$ Permadi Sarkadi, Sistem Hukum Indonesia, Jakarta Universitas Terbuka, 2007, hlm. 11 dalam Rai Mantili, dkk. Jurnal Ilmu Hukum, Padjadjaran, Volume 3 Nomer 1 Tahun 2016.

${ }^{34}$ Mohammad Reza, "Kerjasama KPPU dengan Penyidik Dalam Penanganan Tindak Pidana Hukum Persaingan Usaha”, Jurnal Persaingan Usaha, Edisi 5 Tahun 2011. 
d. Asas non-liquet: hakim tidak boleh menolak perkara yang dihadapkan kepadanya dengan alasan tidak ada undang-undang tidak jelas atau tidak ada;

e. Asas peradilan bebas: obyektif, imparsial dan adil-manusiawi;

f. Hak asasi manusia harus dirumuskan dan dijamin perlindungan dalam undang-undang dasar.

Permasalahan yang timbul dalam praktek, berdasarkan KUHAP bukti permulaan yang cukup dinilai oleh Penyidik yang akan melakukan penyidikan. Ketentuan yang diatur oleh Pasal 44 ayat (5) pada prakteknya tidak dapat dilaksanakan karena penyidik berdasarkan KUHAP, penyidiklah yang menentukan suatu penyelidikan sudah memiliki bukti permulaan yang cukup ataukah belum.

Untuk menjembatani permasalahan tersebut, dalam tata cara pelaksanaan kerjasama dan koordinasi dalam pelaksanaan penanganan perkara praktek monopoli dan/atau persaingan usaha tidak sehat penyerahan putusan KPPU sebagai bukti permulaan yang cukup bagi penyidik Polri untuk melakukan penyidikan adalah putusan KPPU yang tidak dilaksanakan dan juga tidak diajukan keberatan kepada Pengadilan Negeri (PN) oleh Pelaku Usaha terlapor.

Adapun mekanisme penyerahannya adalah sebagai berikut:

a. Dilakukan paparan/gelar perkara (ekspose) oleh KPPU kepada Polri;

b. Pembahasan terhadap materi dan konstruksi hukum perkara yang diserahkan dimaksudkan untuk menentukan ada/tidaknya unsur pidana perkara yang diserahkan;

c. Pertimbangan untuk memutuskan diterimanya perkara yang diserahkan guna ditindaklanjuti dengan proses penyidikan adalah :

(1)Perkara tersebut merupakan tindak pidana dan memenuhi unsur pidana yang dipersangkakan;

(2)Memiliki alat bukti yang cukup sebagaimana diatur dalam Pasal 184 KUHAP.

d. Bila perkara tersebut ditindaklanjuti dengan penyidikan oleh Polri, maka KPPU bertindak sebagai pelapor;

e. Jika syarat sebagaimana dimaksud pada huruf c tidak terpenuhi dan perkara tersebut bukan merupakan tindak pidana, maka penanganan selanjutnya diserahkan kembali kepada KPPU.

Berdasarkan uraian di atas, tidak serta merta MoU dapat menyelesaikan perkara persaingan yang mengandung aspek pidana. Namun demikian dengan adanya MoU paling tidak dapat dijadikan pedoman bersama melalui kerjasama 
antar lembaga sebagai perwujudan adanya Integrated Justice System. Perlunya penyamaan persepsi antara KPPU dan penyidik Polri dalam melaksanakan isi pasal dalam UU Nomor 5 Tahun 1999 sebagai upaya menjamin adanya kepastian hukum dalam penegakan hukum persaingan usaha dan mensinkronkan antara ketntuan yang ada dalam KUHAP dengan UU No. 5 Tahun 1999.

\section{Penutup}

Berdasarkan pada analisis sebagaimana yang diuraikan di atas, maka kesimpulan yang dapat diambil adalah: pertama, peran yang dilakukan oleh Penyidik Polri dalam penegakan hukum persaingan usaha belum sepenuhnya terintegrasi dengan baik dengan KPPU mengingat masih adanya perbedaan penafsiran dan pemahaman dalam menerapkan ketentuan

Kedua, integrasi antara KPPU dan Penyidik Polri diwujudkan dalam bentuk MoU yang ditindak lanjuti dengan kerjasama pembentukan Kelompok Kerja antara KPPU dan Penyidik Polri dalam penanganan perkara persaingan usaha. Masing-masing lembaga tetap menjalankan tugas dan wewenangnya berdasarkan peraturan perundang-undangan yang berlaku dengan berpedoman pada SOP yang telah disepakati bersama sehingga tidak terjadi tumpang tindih kewenangan antara KPPU dan Polri.

\section{Daftar Pustaka}

\section{Buku}

Atmosudirjo, Pramudji, Hukum Administrasi Negara, Bhakti Indonesia, Jakarta, 2010.

Sofyan, Andi dan Asis, Abdul, Hukum Acara Pidana: Suatu Pengantar, Prenada Media, Surabaya, 2017.

Indroarto, Usaha Memahami Undang-Undang tentang Peradillan Tata Usaha Negara, Edisi Baru , Pustaka Sinar Harapan, Jakarta, 2016.

Is, Muhammad Said, Hukum Persaingan Usaha Di Indonesia,: sebagai Upaya Penguatan Lembaga Komisi Pengawas Persaingan Usaha, Malang, Sentara Press, 2016.

Hadjon, M. Philiphus, dkk., Pengantar Hukum Administrasi Indonesia, Introduction To The Administrative Law, Gajah Mada University Press, Yogyakarta, 2017.

Komisi Pengawas Persaingan Usaha, “Laporan Kinerja Tahun 2019”, Jakarta, 2019. 
Lubis, Andi Fahmi, dkk., Hukum Persaingan Usaha , Buku Teks, Edisi Kedua, GiZKPPU, Jakarta, 2017.

Marzuki, Mahmud Peter, Penelitian Hukum, Kencana Perdana Media Group, Edisi Revisi, Jakarta, 2017.

Rahardjo, Satjipto, Masalah Penegakan Hukum: Suatu Tinjauan Sosiologis, Sinar Baru, Bandung, 2010.

Rokan, Kamal, Mustafa, Hukum Persaingan Usaha (Teori dan Prakteknya di Indonesia), PT. Raja Grafindo Persada, Jakarta, 2010.

\section{Jurnal}

Daud, Irmalina Irna, "Evaluasi Terhadap Fungsi dan Kedudukan KPPU”, Jurnal Kebijakan Ekonomi, Vol. 2 No. 1, Agustus 2006 (63-84).

Kagramanto, L. Budi, “Implementasi UU No. 5 Tahun 1999 oleh KPPU”, Jurnal Ilmu Hukum, Yustisia, 2007.

Asshiddiqie, Jimly, "Perkembangan dan Konsolidasi Lembaga Negara Pasca Reformasi", Konpress, 2006.

Mantili, Rai, dkk., "Problematika Penegakan Hukum Persaingan Usaha di Indonesia Dalam Rangka Menciptakan Kepastian Hukum", Jurnal Ilmu Hukum, Padjadjaran, Volume 3 Nomer 1 Tahun 2016, [ISSN2460-1543], [eISSN 2442-9325].

Mohammad Reza, “Kerjasama KPPU dengan Penyidik Dalam Penanganan Tindak Pidana Hukum Persaingan Usaha", Jurnal Persaingan Usaha, KPPU, Edisi 5, Jakarta, 2011.

Supriatna, "Peresekongkolan Bisnis dalam Bentuk Perjanjian Kartel", Jurnal Hukum Positum Vol 1, No. 1, 2016.

Yosefa, Diana, “Efisiensi dan Pelaksanaan Hukum Persaingan Usaha “, Jurnal Persaingan Usaha, edisi 3, Komisi Pengawas Persaiangan Usaha, 2010.

\section{Internet}

Hukum Persaingan Usaha Antara Teks $\mathcal{E}$ Konteks http:// www.reformasihukum.org, Jakarta, 6 Juli 2009.

The Federal Trade Commission, "A Guide to the Federal Trade Commission" www.ftc.gov/bcp/edu/pubs/consumer/general/geno3.shtm, diakses tanggal 12 Mei 2009.

http:/ / kppu.go.id/blog/2016/02/daftar-terlapor-yang-belum-melaksanakanputusan-kppu.

\section{Peraturan Perundang-undangan}

Undang-Undang Nomor 8 Tahun 1981 Tentang Kitab Undang-Undang Hukum Acara Pidana

Undang-Undang Nomor 2 Tahun 2002 Tentang Kepolisian Republik Indonesia 
Undang-Undang Nomor 28 Tahun 1997 Tentang Kepolisisn Negara Indonesia

Undang-Undang Nomor 5 Tahun 1999 tentang Larangan Praktik Monopoli Dan Persaingan Usaha Tidak sehat

Peraturan Presiden Nomor 80 Tahun 2008 tentang Perubahan Atas Keputusan Presiden Nomor 75 Tahun 1999 tentang Komisi Pengawas Persaingan Usaha 